\title{
P137: Effectiveness of a hand hygiene improvement program in doctors: active monitoring and real-time feedback
}

\author{
SR Kim" ${ }^{*}, \mathrm{MH}$ Cho ${ }^{1}$, WJ Kim², JY Song ${ }^{2}$, HJ Cheong ${ }^{2}$ \\ From 2nd International Conference on Prevention and Infection Control (ICPIC 2013) \\ Geneva, Switzerland. 25-28 June 2013
}

\section{Introduction}

Hand hygiene is the single most important intervention to combat infections in diverse health care settings. However, adherence to hand hygiene practice remains low among health care workers, especially in doctors.

\section{Objectives}

The aim of study was to promote hand hygiene compliance in doctors.

\section{Methods}

Hand hygiene practice was monitored by trained observers every three months. We provided performance feedback to doctors using short message service and posters. Also, we conducted the self-check questionnaire survey of hand hygiene performance quarterly. We asked doctors whether they clean hands before contact with patients and clean/aseptic procedures in wards and out-patient room.

\section{Results}

The overall hand hygiene compliance rate increased from a baseline of $49.7 \%$ in fourth quarter of 2011 to $82.3 \%$ in fourth quarter of $2012(p<.001)$. Response rate of self-check questionnaire increased from a baseline of $82.9 \%$ to $93.8 \%(p=.004)$. Compliance with hand hygiene was higher in Wards and higher before clean/aseptic procedures than before contact with patients.

\section{Conclusion}

The self-check questionnaire survey of hand hygiene performance would be useful to increase awareness of

${ }^{1}$ Infection Control Unit, Korea University Guro Hospital, Seoul, Korea, Republic Of

Full list of author information is available at the end of the article hand hygiene, and performance feedback improved the compliance rates in a sustained manner.

\section{Disclosure of interest}

None declared.

\section{Author details}

${ }^{1}$ Infection Control Unit, Korea University Guro Hospital, Seoul, Korea, Republic Of. ${ }^{2}$ Division of Infectious Diseases, Department of Internal Medicine, Korea University Medical College, Seoul, Korea, Republic Of.

Published: 20 June 2013

doi:10.1186/2047-2994-2-S1-P137

Cite this article as: Kim et al:: P137: Effectiveness of a hand hygiene improvement program in doctors: active monitoring and real-time feedback. Antimicrobial Resistance and Infection Control 2013 2(Suppl 1): P137.
Submit your next manuscript to BioMed Central and take full advantage of:

- Convenient online submission

- Thorough peer review

- No space constraints or color figure charges

- Immediate publication on acceptance

- Inclusion in PubMed, CAS, Scopus and Google Scholar

- Research which is freely available for redistribution

Submit your manuscript at www.biomedcentral.com/submit
C) BioMed Central

\section{() Biomed Central}

(c) 2013 Kim et al; licensee BioMed Central Ltd. This is an Open Access article distributed under the terms of the Creative Commons Attribution License (http://creativecommons.org/licenses/by/2.0), which permits unrestricted use, distribution, and reproduction in any medium, provided the original work is properly cited. 